\title{
DIVERSIFIKASI OKUPASI (Studi Sosiologis Terhadap Masyarakat di Pesisir Pantai Malalayang Kota Manado)
}

\author{
Maryam Lamadirisi \\ Dosen pada Program Studi Sosiologi FIS UNIMA
}

\begin{abstract}
Abstrak
Penelitian ini lebih menfokuskan pada bagaimana masyarakat nelayan yang dahulunya menetap di pesisir pantai Malalayang yang kemudian oleh Pemerintah Daerah merelokasi ke daerah ketinggian. Namun mereka tetap melakoni hidupnya sebagai nelayan. Adanya perubahan daerah pertanian menjadi daerah pusat kegiatan, maka beralih pula pola kerja yang selama ini ditekuni (Diversifikasi okupasi adalah memilki beberapa kerja yang dikerjakan). Menurut Darmawan Salman bahwa terjadinya proses keragaman okupasi karena adanya perluasan bidang usaha ekonomi kelompok surplus hasil revolusi hijau ke usaha-usaha non tani (dagang dan industri kecil).

Metode yang digunakan adalah metode kualitatif yang bertitik tolak pada pandangan fenomenologis yang meletakkan penekanannya pada "Vertehen". Dengan obyeknya adalah masyarakat pesisir pantai Malalayang. Hasil penelitian adalah a. Faktor-faktor yang mendorong masyarakat pesisir pantai dan nelayan Malalayang melakukan diversifikasi adalah karena lahan tempat tinggal digunakan oleh Pemerintah daerah (relokasi $1 \mathrm{~km}$ dari tepi pantai) sehingga mereka harus berusaha untuk dapat menghidupkan keluarganya. b. Faktor-faktor yang menjadi hambatan dalam upaya dibeversivikasi okupasi adalah minimnya lahan dan modal usaha sehingga sebagian mereka hanya dapat membantu saudaranya yang memiliki kios. c. Signifikan diversivikasi okupasi dengan mobilitas status, ternyata ada beberapa keluarga yang telah memiliki usaha yang tetap dan kemudian menjadi tokoh agama di Malalayang.
\end{abstract}

\section{Kata Kunci: Diversivikasi, Okupasi, Masyarakat Pesisir Pantai}


PENDAHULUAN

Berbagai kebijakan telah ditempuh pemerintah Republik Indonesia dalam melakukan pembangunan. Pada zaman orde baru pembagunan diprioritaskan kepada pertumbuhan ekonomi dengan kebijakan melaksanakan modernisasi pertanian pedesaan. Hal ini didasarkan kepada pertimbangan bahwa sebagian besar penduduk Indonesia tinggal di daerah pedesaan. Modernisasi pertanian dengan memanfaatkan teknologi pertanian diintrodusir kepada petani melaiui istilah yang dikenal dengan sebutan "revolusi hijau" (menggunakan bibit unggul, pupuk, dan pembasmi hama) yang kemudian membawa perubahan pada cara-cara bertani. Gerakan Revolusi Hijau sebagaimana telah umum diketahui di Indonesia tidak mampu untuk menghantarkan Indonesia menjadi sebuah negara yang berswasembada pangan secara tetap, tetapi hanya mampu dalam waktu lima tahun. Disamping itu, Revolusi Hijau juga telah menyebabkan terjadinya kesenjangan ekonomi dan sosial pedesaan karena ternyata Revolusi Hijau hanyalah menguntungkan petani yang memiliki tanah lebih dari setengah hektar, dan petani kaya di pedesaan, serta penyelenggara negara di tingkat pedesaan. Sebab sebelum Revolusi Hijau dilaksanakan, keadaan penguasaan dan pemilikan tanah di Indonesia sudah timpang, akibat dari gagalnya pelaksanaan Pembaruan Agraria yang telah mulai dilaksanakan pada tahun 1960 sampai dengan tahun $1965^{77}$.

Upaya untuk mencapai swasembada pangan terus diupayakan oleh pemerintah. Dalam era kepemimpinan Presiden Susilo Bambang Yudoyono Pemerintah Republik Indonesia melaiui Kementerian Pertanian (Kementan) menyiapkan dana Rp 8,3 triliun untuk merealisasikan program swasembada pangan di tahun 2014. Lima komoditas yang ditargetkan swasembada tahun depan yaitu beras, jagung, kedelai, daging dan gula rafinasi. Hal ini diungkapkan Menteri Pertanian Suswono dalam Rapat Kerja (Raker) dengan Komisi IV DPR RI di Gedung DPR RI, Senayan, Jakarta, di Gedung DPR, Kamis
(5/9/2013)(http:/id.wikipedia.org/wiki/Revolusi _hijau).

Upaya mensejahterakan masyarakat terus berlangsung. Namun kenyataan lapangan sampai sekarang ini kemiskinan masih mengelayuti sebagian masyarakat Indonesia terutama dari golongan petani dan nelayan. Petani miskin dan tunakisma (rumah tangga petani berlahan sempit) terpaksa harus melakukan upaya diversifikasi okupasi ke berbagai sektor lainnya baik di desa sendiri maupun keluar dari desanya. Diversifikasi okupasi ternyata bukan saja dilakukan oleh petani miskin dan tunakisma, tetapi juga dilakukan oleh petani kaya dengan pola yang berbeda. Menurut Triyono (1992). pergeseran okupasi para petani ke luar pertanian pada dasarnya sangat ditentukan oleh kondisi-kondisi sosial ekonomi yang dibawa dari dunia pertanian. Berpijak pada kondisi sosial ekonomi yang dibawa dari sistem produksi pertanian itu, sangat mungkin membawa terjadinya pergeseran pola yang berbeda dari berbagai kelompok sosial ekonomi yang ada.

Diversifikasi okupasi yang dilakukan oleh rumah tangga untuk dapat meningkatkan kesejahteraan ekonomi atau sekedar aman subsistensi bagi petani berlahan sempit dan tunakisma dan upaya re-akumulasi kapital bagi petani kaya berlahan luas. Upaya yang dilakukan oleh rumah tangga petani dengan tujuan tersebut di atas sudah barang tentu membawa dampak bagi terjadinya perubahan sosial antara lain mobilitas status. Selama diversifikasi berlangsung, meningkatnya pendapatan akan mengembangkan perilaku ekonomi dalam mengkonsumsi benda-benda material kebutuhan konsumsi pokok rumah tangga perilaku demikian akan membawa perubahan gaya hidup tertentu yang nantinya akan menumbuhkan terbentuknya kualiftkasi status sebagai dasar terbentuknya stratifikasi sosial dalam masyarakat.

Bagi masyarakat petani dan nelayan di pinggiran kota, fenomena diversifikasi okupasi semakin nyata terlihat. Hal ini dimungkinkan karena lebih besarnya kemungkinan untuk mendapatkan pekerjaan (okupasi) di luar sektor usaha tani dan nelayan sebagai akibat dekatnya dengan kota. Kota umumnya memerlukan 
tenaga kerja di berbagai sektor usaha dan jasa untuk mendukung aktivitas kota.

Desa Malalayang Timur, Malalayang Satu, dan Malalayang Dua yang terbentang scpanjang pantai Malalayang dahulunya adalah desa pinggiran di luar Kota Manado yang didiami oleh banyak petani dan nelayan. Setelah perluasan kota Manado pada tahun 1980-an maka desa Malalayang keseluruhannya menjadi wilayah kota Manado.

Diversifikasi okupsi dewasa ini pada masyarakat pesisir pantai Malalayang Manado makin menampak karena mulai menghilangnya lahan pertanian yang berganti dengan lahan pemukiman dan lahan usaha. Disepanjang jalur jalan Malalayang yang terbentang dari Timur ke Barat sampai batas kota telah tumbuh usahausaha dagang dengan skala kecil sampai menengah. Fenomena ini merupakan indikasi terjadinya diversifikasi okupasi yang berdampak pada terjadinya mobilitas status di kalangan rumah tangga masyarakat pesisir pantai Malalayang Manado.

Fenomena diversifikasi okupasi di pesisir pantai Malalayang Manado menarik untuk diteliti dan dikaji dari berbagai sudut pandang. Pada kesempatan ini, peneliti ingin mengkajinya dari sudut pandang ilmu Sosiologi.

Fokus masalah penelitian ini adalah pada pengkajian status okupasi masyarakat yang dulunya berprofesi sebagai petani dan nelayan, dan sekarang ini telah beralih usaha baik secara penuh maupun yang masih menekuninya sebagai usaha sampingan.

Masalah dalam penelitian ini dapat dirumuskan sebagai berikut:

1. Faktor-faktor apa yang mendorong masyarakat tani dan nelayan pesisir pantai Malalayang untuk melakukan diversifikasi okupasi?

2. Faktor-faktor apa saja yang menjadi hambatan dalam upaya diversifikasi okupasi?

3. Apakah diversifikasi okupasi yang dilakukan secara signifikan mempengaruhi mobilitas status?
Penelitian ini diharapkan berguna dalam memperkaya khasanah ilmu pengetahuan sosial pada umumnya dan pengetahuan dalam bidang studi sosiologi khususnya.

Dari segi praktisnya, penelitian ini diharapkan dapat memberikan masukan pada instansi terkait di kota Manado untuk mengambil langkah-langkah strategis dalam pemberdayaan masyarakat kota umumnya, dan masyarakat pesisir pantai yang dulunya berprofesi sebagai petani dan nelayan.

\section{KAJIAN TEORETIK}

Diversifikasi okupasi tidak hanya dilakukan oleh rumah tangga petani berlahan sempit (petani gurem) karena kemiskinannya, tetapi juga dilakukan oleh petani berlahan luas (petani kaya), yang sudah barang tentu akan berbeda pola diversifikasinya. Darmawan Salman mengatakan bahwa ada beberapa skenario terjadinya proses keragaman okupasi di pedesaan. Pertama, perluasan bidang usaha ekonomi kelompok bersurplus hasil revolusi hijau ke usahausaha non tani (jasa, dagang, dan industri kecil). Kedua, kelompok okupasi baru yang mengalami penguatan melalui aliran dana dari pusat ke desa dan pengelola aliran dana tersebut (Darmawan).

Adanya perbedaan pola diversifikasi okupasi di antara lapisan petani, berangkat dari perbedaan status sosial ekonomi, kekuasaan, dan tujuannya. Petani berlahan luas dengan surplus yang melimpah dari hasil pertanian memiliki banyak pilihan. Apakah akan melakukan diversifikasi okupasi dengan tetap tidak meninggalkan usaha taninya atau memperkuat basis pertanian dengan menambah jumlah lahan pertaniannya. Sedangkan petani miskin yang kurang diuntungkan oleh teknologi pertanian melakukan diversifikasi okupasi ke non pertanian (dengan kerja serabutan atau mengikuti keahliannya) merupakan alternatif untuk menyelamatkan dan meningkatkan taraf kesejahteraannya dengan kemungkinan hasil yang tidak pasti, apakah akan meningkat, tetap, atau menurun tingkat kesejahteraannya. 


\section{Karakteristik sosial masyarakat pesisir}

Secara sosiologis karakteristik masyarakat pesisir berbeda dengan karakteristik masyarakat agraris seiring dengan perbedaan karakteristik sumberdaya yang dihadapi. Masyarakat agraris yang dipresentasikan kaum petani menghadapi sumberdaya yang terkontrol, yaitu pengelolaan lahan untuk produksi suatu komoditas dengan output yang relative dapat diprediksi. Sifat produksi seperti itu memungkinkan tetapnya lokasi produksi sehingga mobilitas usaha relative renda dan elemen risikopun tidak terlalu besar.

Dalam hal ini usaha pembudidaya ikan dapat digolongkan ke dalam usaha masyarakat pertanian (agraris) karena sifat sumberdaya yang dihadapi relative mirip.Kemiripan ini terletak pada penentuan jumlah, tempat, dan waktu pembudidayaan.Dalam hal ini pembudidayaan ikan dilakukan dengan ditangkap sehingga pola panennya lebih terkontrol. Pola panen yang terkontrol terjadi karena adanya input yang terkontrol pula. Jumlah input produksi (benih, makanan, teknik, dan lainnya) sudah ditentukan untuk mencapai output yang diharapkan (Satria, 2010:7).

Karakteristik tersebut berbeda dengan nelayan.Nelayan menghadapi sumberdaya yang hingga saat ini bersifat open access. Karakteristik sumberdaya seperti ini menyebabkan nelayan harus berpindah-pindah untuk memperoleh hasil maksimal.Dengan demikian elemen risikonya menjadi sangat tinggi.Kondisi sumberdaya yang berisiko menyebabkan mesyarakat nelayan memiliki karakter keras, tegas, dan terbuka (Satria, 2010:7).

\section{Struktur Sosial Masyarakat Pesisir}

Menurut Kornblum struktur sosial merupakan pola Perilaku berulang-ulang yang memunculkan hubungan antarindividu dan antar kelompok dalam masyarakat. Dalam mengkaji struktur sosial ini, ada dua konsep penting, yaitu status dan peranan. Status adalah suatu kupmpulan hak dan kewajiban, sedangkan peranan adalah aspek dinamis dari status.

\section{Patron-Klien: Ciri Umum Struktur Sosial masyarakat Pesisir}

Sementara itu, James Scott (Satria, 2010:7) melihat hubungan patron klien sebagai fenomena yang terbentuk atas dasar ketidaksamaan dan sifat fleksibilitas yang tersebar sebagai suatu sistem pertukaran pribadi. Dalam pertukaran itu, berarti ada arus dari patron ke klien dan sebaliknya. Masih menurut Scoot, arus dari patron ke klien meliputi:

(1)Penghidupan subsisten dasar, berupa pemberian pekerjaan tetap, penyediaan saprodi (sarana produksi padi) jasa pemasaran,dan bantuan teknis,

(2) Jaminan krisi subsisten berupa jaminan yang diberikan pada saat klien menghadapi kesulitan ekonomi,

(3) Perlindungan terhadap klien dari ancaman pribadi ( musuh pribadi) Maupun ancaman umum (tentara, pejabat, atau pemungut pajak),

(4) Memberikan jasa kolektif berupa bantuan untuk mendukung sarana umum setempat (sekolah, tempat ibadah, atau jalan) serta mendukung festival serta perayaan desa. Berdasarkan tata hubungan tadi, jelaslah bahwa hubungan antara nelayan dengan patron yang menguasai sumberdaya tidak sama.

Hubungan patron klien memiliki karakteristik yang berbeda-beda pada masingmasing daerah. Hal ini diperlihatkan pola hubungan patron klien pada masyarakat pesisir pantai Malalayang Manado.

\section{Metodologi Penelitian}

Penelitian ini pada dasarnya menggunakan pendekatan kualitatif yang bertitik tolak pada pandangan fenomenologis yang meletakkan penekanannya pada "verstehen" yaitu pemahaman makna tingkah laku manusia sebagaimana yang dimaksudkan oleh pelakunya sendiri, yang bagi peneliti sendiri sifatnya interpretif (Weber, dalam Bogdan dan Taylor, 1975 dalam Sugionao, 2011).

Penelitian ini dilakukan dalam tiga tahap, yaitu tahap orientasi, tahap eksplorasi, dan tahap analisis data. Tahap orientasi bermaksud 
untuk memperoleh gambaran yang lengkap dan jelas keadaan di lapangan. Teknik ini menggunakan observasi dan dokumen. Hal-hal yang dianggap unik dan relevan dengan masalah penelitian diberikan perhatian khusus. Tahap eksplorasi memberikan indikasi permasalahan yang diteliti, pada tahap ini mulai dilakukan pelacakan. Untuk itu observasi lebih diintensifkan dan wawancara mulai dilaksanakan serta semakin terstruktur. Observasi dan wawancara pada tahap ini didasarkan pada observasi dan studi dokumentasi pada tahap orientasi. Data-data yang diperoleh langsung dianalisis, ditafsirkan, disimpulkan dan diverifikasi.

Tahap pengecekan atau pengujian keabsahan data. Pada tahap ini data diuji kredibilitasnya, konsistensinya, diadakan audit, dilakukan konfirmasi dengan informan.

Penelitian ini bertujuan untuk mengetahui tentang :

1. Faktor-faktor apa yang mendorong masyarakat tani dan nelayan pesisir pantai Malalayang melakukan diversifikasi okupasi.

2. Faktor-faktor apa saja yang menjadi hambatan dalam upaya diversifikasi okupasi pada masyarakat pesisir pantai Malalayang Manado.

3. Signifikansi diversifikasi okupasi yang dilakukan terhadap mobilitas status petani dan nelayan.

Penelitian ini dilakukan dalam masyarakat sekitar pesisir pantai Malalayang yang terletak di kelurahan Malalayang Dua. Responden yang dijadikan sebagai sumber data dalam penelitian ini adalah anggota masyarakat yang terkait langsung maupun yang tidak langsung tempat berdomisilinya masyarakat pesisisir pantai di kelurahan Malalayang II kecamatan Malalayang kota Manado. Anggota masyarakat yang terkait langsung adalah para pengelola rumah makan, tukang, nelayan dan petani serta pekerja lepas. Sedangkan anggota masyarakat yang tidak langsung terkait adalah penjaja makanan dan minuman yang tidak memiliki kios namun hanya gerobak atau punya kios namun bukan yang ada di deretan pesisir pantai namun sebelah jalan sebelah kiri yang mendekati perbukitan atau sebelah kanan menuju arah Kalasey atau perbatasan kota Manado.

Teknik yang digunakan dalam pengumpulan data adalah melaiui tiga tahap, yaitu tahap orientasi, eksplorasi, dan tahap analisis data. Tahap orientasi bermaksud untuk memperoleh gambaran yang lengkap dan jelas keadaan di lapangan.Teknik ini menggunakan observasi dan dukomen. Halhal yang dianggap unik dan relevan dengan masalah penelitian diberikan khusus. Tahap eksplorasi memberikan indikasi permasalahan yang diteliti, pada tahap ini mulai dilakukan pelacakan.Untuk observasi lebih diintensifkan dan wawancara mulai dilaksanakan serta semakin terstruktur. Observasi dan wawancara pada tahap ini didasarkan pada observasi dan studi dokumentasi pada tahap orientasi. Data-data yang diperoleh langsung dianalisis, ditafsirkan, disimpulkan dan diverifikasi. Tahap pengecekan atau pengujian keabsahan data. Pemeriksaan keabsahan data dilakukan dengan cara trianggulasi

\section{Hasil Penelitian}

\section{Gambaran Umum Lokasi Penelitian}

Daerah pesisir Malalayang memanjang dari wilayah bagian Timur ke arah bagian Barat. Daerah yang dikenal dengan Manado bagian Selatan Tenggara ini adalah kecamatan Malalayang yang membawahi 9 Kelurahan yaitu:

-Kelurahan Winangun I

-Kelurahan Winangun II

-Kelurahan Batu Kota.

-Kelurahan Kleak

-Kelurahan Bahu

-Kelurahan Malalayang Timur

-Kelurahan Malalayang I (di bagian Tengah)

-Kelurahan Malalayang Barat.

-Kelurahan Malalayang Dua.

Luas lahan Kelurahan Malalayang Dua adalah $300 \mathrm{Ha}$, terdiri dari beberapa lingkungan: Lingkungan $1=35$ ha, lingkungan $2=50$ ha, lingkungan $3=46$ ha, lingkungan 4 $=54$ ha, lingkungan $5=95$ ha, lingkungan $6=$ 8 ha, lingkungan $7=55$ ha, lingkungan $8=8$ ha, lingkungan $9=7$ ha. 
Kelurahan Malalayang Dua ini dahulunya ditempati oleh mereka dari sub etnis Bantik. Etnis Bantik ini dalam bahasanya kalau diteliti seperti bahasa dari kepulauan Sangihe. Bentuk tubuh dan kulitnya juga mirip dengan mereka yang dari seberang lautan Kepulauan Sangihe. Suku Bantik ini mendiami pesisir Kota Manado di mulai dari wilayah Utara Wori sampai ke wilayah Selatan Malalayang.

Pemekaran wilayah Malalayang masuk ke Kota Manado, maka wilayah ini terbuka menerima para pendatang yang memasuki wilayah ini dengan membeli tanah/lahan pertanian masyarakat Bantik. Kemudian perpindahan Rumah Sakit Pusat Prof. Kandouw semakin bertambah para urban ke Malalayang. Kemudian pembukaan stasiun Bus antarkota dipindahkan ke Malalayang yang sekarang masuk Malalayang Dua semakin banyak masyarakat yang mencari tempat tinggal di wilayah ini. Sehingga sekarang Malalayang Dua terdiri dari berbagai etnis yang mendiami wilayah ini.

Kelurahan Malalayang Dua ini memiliki wilayah pantai yang cukup dikenal oleh masyarakat kota Manado dan sekitarnya sebagai wilayah wisata pantai dan wisata kulinernya. Banyak masyarakat yang menggunakan pantai ini sebagai obyek wisata yang murah meriah, karena tidak ditarik biaya masuk, yang penting membawa bekal atau juga bisa membeli beraneka dagangan yang ditawarkan oleh para pedagang yang sudah memiliki kios yang diberikan oleh Pemerintah Daerah Kota Manado dan diawasi oleh Pemerintah Daerah Kecamatan Malalayang.

Masyarakat yang memiliki kios juga ada yang bekerja sebagai nelayan karena pekerjaan utama, sementara kios diolah oleh keluarga. Hasil nelayan biasanya dijual mentah di depan kios atau sudah di beli langsung oleh masyarakat yang melewati jalur trans Sulawesi, dan masyarakat sekitar. Nelayan ini ada yang memiliki perahu katinting ada juga yang memiliki perahu besar.

\section{Keadaan Penduduk dan Matapencaharian Hidup}

Jumlah penduduk kelurahan Malalayang adalah 10354 jiwa. Terdiri dari 2016 KK (kepala keluarga). Jumlah penduduk tidak merata sesuai topografi wilayah Malalayang Dua yang berjumlah 2045 jiwa. Penduduknya ada yang mendiami pesisir pantai dan ada yang di daratan tinggi (bukit), karena bentuk pesisir pantai yang landai diikuti dengan daratan yang menanjak ke perbukitan sehingga konsentrasi penduduk tidak merata.

Jumlah penduduk yang terbanyak dari tiap-tiap lingkungan adalah Lingkungan $\mathrm{V}$ yang ada di dekat stasiun Malalayang demikian disebut oleh masyarakat. Lingkungan I ini wilayah dari Manado lebih dulu ditemukan, dekat dengan Rumah Ssakit dan Fakultas Kedokteran dan Akademi Perawat Politeknik, yang berjumlah 1350 jiwa, ini terjadi karena lokasi/wilayah ini dekat dengan lokasi Fakultas Kedokteran UNSRAT, dan Akademi Perawat di wilayah Kelurahan Malalayang Barat di mana ada Rumah Sakit Umum Prof. Kandouw yang dimiliki kota Manado sebagai rumah sakit Pusat yang ada di Sulawesi Utara yang dikuti dengan lingkungan II yang berjumlah 1357 jiwa.

Kemudian lingkungan IX yang berjumlah 1218 ini dekat tempat wisata sesudah stasiun Malalayang daerah tempat wisata pantai. Wilayah ini semakin diminati oleh masyarakat karena daratan tingginya yang oleh masyarakat agak tinggi sehingga kalau tsunami mereka masih bisa selamat.

Lingkungan yang lainnya karena masih banyak yang belum dihuni oleh masyarakat yang masih merupakan lahan tanaman palawija dan pohon kelapa sehingga pebduduknya masih kurang. Namun juga ada lahan yang sudah dimiliki oleh mereka yang berduit namun belum didirikan tempat hunian dan suda dipagar agar aman tanahnya dari penjarahan mereka yang dari mana saja yang akan mencari tempat kerja di Manado.

Karena wilayah ini merupakan tempat pusat kegiatan di ujung kota Manado, maka penduduknya terdiri dari berbagai etnis dan Agama. Etnis terdiri dari, Minahasa, Bantik, Gorontalo, Sangihe, Sitaro, Talaud, BugisMakassar, Posso, Palu, Buton, Ambon, Ternate, Papua, Jawa, Bali, dan Sumatera. Hampir seluruh suku di Indoneia ada di Kelurahan Malalayan Dua ini karena di sini pusat kegiatan 
Kesehatan, Pendidikan dan stasiun mobil (angkutan antar kota) Manado Amurang, Kotamobagu, Duloduo, sampai ke Gorontalo dan Wilayah Sulawesi Tengah dan Sulawesi Selatan. Jalur jalan trans Sulawesi terdapat di wilayah ini untuk memasuki Kota Manado dan seterusnya.

Wilayah bagian landai adalah pantai yang wilayah wisata laut (tempat mandi-mandi yang murah meriah karena tidak menggunakan tiket masuk dan banyak kios-kios yang sudah ditata rapi oleh Pemerintah Daerah, dijual makanan ringan khas manado/nasi kuning, pisang goreng, jagung rebus, tinutuaan atau bubur Manado dan lain-lain).

Mereka yang dahulunya menetap di pesisisr pantai oleh Pemerintah Daerah di relokasi ke daratan yang agak tinggi sekitar 1 $\mathrm{km}$ dari tepi pantai. Namun karena pekerjaan dan kebiasaan sebagai nelayan mereka tetap melaut. Dan keluarganya yang sudah biasa berjualan di tepi pantai akhirnya oleh Pemerintah Daerah di relokasi membuat kioskios yang ada seperti sekarang ini.

Bagi laki-lakinya kalau tidak melaut mereka memperbaiki alat-alat nelayannya atau membantu istri-istri mereka yang berjualan di kios, namun ada juga yang tidak memiliki kios.Masih ada juga yang berjualan bukan di tempat/kios yang disediakan oleh Pemerintah Daerah, tetapi membuat kios di seberang jalan dari kios-kios tersebut.Dari pantauan peneliti ada juga yang berubah pekerjaannya dari nelayan menjadi pekerja bangunan, karena banyak rumah-rumah yang dibangun di lokasi ini.

Temuan-temuan di lapangan ternyata banyak PNS karena wilayah ini banyak terdapat perumahan yang disediakan oleh Bank Tabungan Negara untuk masyarakat yang dapat dicicil. Selanjutnya swasta mereka ini adalah para urban yang datang untuk mencari pekerjaan karena wilayah Malalayang merupakan daerah pusat bisnis. Adanya Mall dan pusat jajanan atau tempat makan bagi mereka yang akan mengadakan makan bersama atau biasanya ada tamu dari luar Manado di antar makan ke tempat makan yang banyak menyediakan lauk dari laut (sea food) karena
Manado terkenal dengan Bunaken dan ikan yang masih segar.

Selanjutnya tempat ketiga diduduki oleh mereka yang berprofesi sebagai tukang, hal ini terjadi karena wilayah Malalayang ini merupakan daerah pertanian yang sudah dibuka untuk umum. Sekitar tahun tujuh puluhan daerah ini merupakan daerah tertutup dimana orang yang masuk ke wilayah ini ditanyai, begitu lewat jembatan Bahu sudah banyak anakanak muda yang duduk-duduk di tepi jembatan dan wilayah ini merupakan wilayah tawuran bagi mereka yang melanggarnya.

Sebagai tukang tidak perlu pendidikan yang tinggi yang penting bisa menggunakan alat-alat pertukangan, namun ada juga mereka yang hanya sebagai pembantu atau biasa disebut kenek. Mereka ini perlu keterampilan dalam pertukangan yang penting bisa melakuka napa yang disuruh oleh kepala basnya.

Selanjutnya nelayan yang menduduki tempat keempat, karena dulunya masyarakat ini mendiami pesisir pantai Malalayang namun pogram pemerintah membersihkan pesisir pantai untuk dijadikan wilayah wisata bagi kota Manado.

Kelima adalah lebih banyak yang dilakukan oleh ibu-ibu rumah tangga yang telah menjadi kepala rumah tangga, ditinggalkan oleh suaminya, baik yang meninggal maupun yang ditinggal karena suaminya kawin lagi. Pekerjaan mereka adalah membantu pekerjaan Ibu-ibu yang bekerja sebagai PNS di rumahnya seperti mencuci pakaian, memasak maupun menjaga anak ada juga yang membantu dikios-kios atau di swalayan dan toko-toko yang banyak dibuka di sepanjang jalan.

Pekerjaan yang dimiliki masyarakat sedikit adalah pekerjaan ABRI, Polisi dan yang memiliki kios. Ini karena pendidikan dan kemampuan mereka dalam mengelola keuangan dan kedekatan dengan pemerintah agar bisa mendapatkan tempat (mereka yang duluan berjualan hanya dengan menggunakan payung atau berjualan secara terbuka dan mereka yang dulunya tinggal di pesisir pantai Malalayang). 
Faktor-faktor mendorong masyarakat petani dan nelayan pesisir pantai Malalayang melakukan diversifikasi Okupasi

Berbagi faktor yang mendorong masyarakat pesisir pantai ini melakukan diversifikasi adalah, karena mereka melihat adanya peluang- peluang kerja yang terdapat di wilayah ini dengan terbukanya wilayah Malalayang sebagai pusat kegiatan.

Peneliti bertanya kepada tante Nortje" kapan berjualan disini? Jawabnya "sudah lama torang disini dari mulai bajual cuma deng taru meja kong tu makanan taru diatas, torang somamasa dari rumah Cuma bajual no disini. Kalu ujang torang ba sepi dipinggi orang pe rumah di atas. Artinya kami sudah lama berjualan disini hanya menggunakan meja dan makanan diletakkan diatas, makanan sudah dimasak dari rumah, disini hanya untuk berjualan. Kalau hujan kami berteduh di rumah orang di bagian atas.

Selanjutnya pertanyaan diajukan kepada bapak Nel panggilan sehari-hari yang nama aslinya Comeles, pertanyaan yang diajukan selain membantu sang istri di kios apalagi pekerjaannya " kita kalo nyanda kalaut kita baku tolong deng maitua ba jual maar biasanya kita kalaut kalo malamhari maar nyanda tantu karena kalo torang dapa lia ada burung berarti ada ikang torang capat-capat turunka pante ba mangail.Kalo siang nyanda kalao, kalo sadiki orang babalanja kita kase bae tu jala ikang.

Artinya kalau saya tidak melaut, maka saya membantu istri berjualan tetapi itu biasanya saya melaut pada malam hari, namun kadang disiang hari bila ada burung yang berebutan makanan di laut pertanda adanya rombongan ikan, maka kami cepat-cepat melaut agar bisa mendapatkan ikan yang banyak. Kalau siang hari tidak melaut maka saya memperbaiki jala.

Menurut Boy yang masih muda kurang lebih 30 puluhan umurnya.

Biasanya kita baku bantu deng maitua deng papa kalo kita nyanda ada pekerjaan tambahanfba sopir) karena kita bisa bawa oto atau baku bantu biking rumah. Biasanya saya mem bantu istri dan bapak kalau tidak ada pekerjaan tambahan yaitu sebagai sopir ataumembantu mereka yang membangun rumah.

Ibu Sartje berkata, kita Pegawai Negeri Sipil sekarang mar kita tetap bajual, karena kit ape sudara-sudara baku bantu untuk bajual, sekarang kita ape anak kalu pulang sekolah baku tolong ba jual. Lumayanno for mo bantu kita pe anak pe doi sekolah soalnya paitua so meninggal. Artinya saya Pegawai Negeri Sipil sekarang tetapi kita tetap berjualan, dimana jika saya pergi kerja saudara-saudara yang menjaga jualan, juga anak kalau pulang sekolah membantu berjualan, untuk membantu keuangan sekolah anak saya karena suami sudah meninggal.

Ini mereka yang memberikan jawaban yang saya rasa sudah cukup untuk menjelaskan bahwa mereka memiliki beberapa pekerjaan di dalam kehidupannya.

Faktor-faktor yang menjadi hambatan dalam upaya diversifikasi okupasi pada masyarakat pesisir pantai.

Bagi masyarakat yang dulunya hanya bisa menjual pisang goring menandakan bahwa modal usahanya hanya pas-pasan untuk makan sehari- hari. Ada juga bapakbapak dan Ibu-ibu yang tidak melanjutkan pendidikan sehingga tidak bisa bekerja di kantor. Dengan dibukanya rumah sakit pusat Dr. Kandou banyak yang bekerja sebagai tukang bersih (cleaning servis), namun ada juga yang tetap berjualan.

Ibu Noni memberikan alasan mengapa beliau membantu di tetangganya yang berjualan di kios.

Kita hanya baku bantu mamasa karena kita nyanda punya modal deng kita Cuma bisa bakarja bagini supaya dapa doi for kita pe anak mo sekolah Biar kita nyanda dapa ijazah mar kit ape anak harus sekolah Dulu kita babaso orang pep e pakaiang. Artinya saya hanya membantu memasak, karena tidak punya modal usaha sehingga pekerjaan seperti ini agar anak bisa sekolah.Walaupun saya tidak dapat ijazah namun anak harus sekolah.Dahulunya saya mencuci pakaian orang. 
c. Signifikansi diversifikasi okupasi yang dilakukan terhadap mobilitas status petani dan nelayan masyarakat pesisir pantai.

Dengan adanya divesifikasi okupasi menyebabkan masyarakat pesisir pantai ini ada yang sudah hidup mapan artinya, mereka sudah memiliki rumah yang cukup sehat dan sudah permanen dan ada juga yang sudah memiliki mobil atau sepeda motor.

Pekerjaan nelayan masih digeluti namun saat-saat tertentu membawa mikro atau menjadi sopir bagi yang membutuhkan.ini tergantung kadang juga membantu orang membangun rumah.

Kami menghubungi seorang bapak muda yang gesit biasa dipanggil om Boy:

Bagemana om bisa seperti sekarang ini so punya rumah yang bagus deng so punya oto beliau juga sudah diangkat sebagai syamas di Gereja. Jawabnya, kitalia kitape orang tua dulu pe susah kong kitaba pikir kita nimau sama deng dorang. Kita Cuma tamat SMP mar kita karja keras, orang suruh bikin apa saja kita mau. Sekarang maitua buka kios di pante jadi torang bole baku bantu. Artinya bagaimana om bisa seperti sekarang ini sudah punya rumah sehat yang permanen punya mobil, beliau juga sudah duangkat sebagai syamas di gereja. Jawabnya saya melihat orang tua dahulu susah ini mengakitkan saya harus tidak boleh sama dengan mereka. Saya hanya tamat SMP tetapi saya kerja keras, siapa saja yang memberikan kerja saya kerjakan. Sekarang istri membuka kios di pantai jadi saling membantu.

Ini menandakan bahwa dengan perbaikan kehidupan akan meningkatkan status seseorang yang awalnya hanya menjadi anggota di Gereja kini bisa duduk di kepemimpinan Gereja. Juga sudah memiliki rumah dan kendaraan ini menndakan bahwa status ekonomi bisa meningkatkan status di masysrakat.

\section{Pembahasan}

Dari hasil penetian yang ditemukan temyata bahwa kehidupan masyarakat pesisir pada awalnya adalah nelayan, yang kemudian berkembang menjadi pengusaha kelasmenengah kebawah (memiliki kios makanan), namun belum meninggalkan pekerjaan awalnya.

\section{Faktor-faktor mendorong masyarakat petani dan nelayan pesisir pantai melalayang melakukan diversifikasi Okupasi}

Perkembangan pekerjaan/diversifikasi okupasi sesuai dengan perubahan wilayah tempat tinggal yang dahulunya adalah wilayah nelayan dan pertranian di daerah ketinggian atau sebelah jalan kini yang telah menjadi perkampungan yang berkembang cukup pesat.

Dengan berubahnya wilayah Malalayang menjadi pusat kegiatan di wilayah selatan Kota Manado yang menjadikan wilayah ini dari homogeny pertanian dan nelayan menjadi kota yang heterogen dimana perkembangan okupasi yang begitu heterogen.

Banyaknya urban yang datang dan menetap di wilayah Malalayang ini membuka lahan menjadi perumahan, yang akhirnya berakibat pada berkembangnya berbagai pekerjaan yang akan dikerjakan bagi mereka yang membutuhkan.

Faktor-faktor yang menjadi hambatan dalam upaya diversifikasi okupasi pada masyarakat pesisir pantai.

Hambatan bagi mereka masyarakat pesisir pantai yang dahulunya adalah nelayan dan petani adalah kurangnya modal usaha untuk mengembangkan usahanya.Begitu mereka menjual lahan pertanian harus dibagikan ke keluarga sehingga hasil bagi keluarga-keluarga itu semakin kecil.ini tidak cukup untuk berusaha sebagai pengusaha kecil sehingga mereka yang tidak memiliki modal bekerja sebagai tukang atau serabutan.

Signiflkansi diversifikasi okupasi yang dilakukan terhadap mobilitas status petani dan nelayan masyarakat pesisir pantai.

Bagi mereka yang bekerja ulet mendatangkan hasil yang sepadan yakni bisa memiliki rumah dan kendaraan roda emapat maupun kendaraan roda dua. Ini 
menyebabkan statusnya di masyarakat menjadi baik dengan menjabat sebagai syamas di Gereja.

Ini menandakan bahwa dengan membaiknya ekonomi seseorang akan meningkatkan status di masyarakat. Dan akan menjdi contoh bagi masyarakat yang lainnya, bahwa dengan bekerja yang ulet akan menhasilkan sesuatu yang terbaik.

\section{Penutup}

\section{Kesimpulan}

1. Masyarakat yang pada awalnya adalah nelayan masih ada yang tetap pekerjaannya dan dikembangakan dengan membuka kioskios yang menjual makanan khas Manado dipinggiran pantai lokasi wisata pantai yang banyak diminati masyarakat Manado. Merupakan pendorong bagi masyarakat pesisir pantai

2. Yang menjadi penghambat diversifikasi okupasi adalah bagi mereka yang dulunya meliki lahan kecil waktu di jual dibahagi ke keluarga sehingga hasil sedikit menyebabkan tidak memiliki modal usaha.

3. Diversifikasi okupasi secara signifikan dapat meningkatkan kesejahteraan bagi keluarga. Tentunya dibarengi dengan kerja keras, sehingga dapat menghasilkan sesuatu yang berharga. Ini juga dapat meningkatkan status sosial.

\section{Saran}

1. Diharapkan Pemerintah Daerah memberikan bantuan kredit menengah agar bisa lebih leluasa menjual berbagai macam kebutuhan yang diminati masyarakat yang pergi ke wilayah wisata ini, atau mereka yang akan bepergian ke luar kota.

2. Bagi masyarakat yang mendiami kios-kios ini agar dapat lebih memenej keuangan agar dapat meningkatkan kesejahteraan keluarga.

\section{DAFTAR PUSTAKA}

Adimihardja, Kusnaka. 1993. Kebudayaan dan Lingkungan. Studi Bibliografi. llham Jaya. Bandung.
Adiratma, Rukasah. 1970. Income of Rice Farmers and Their Marketable Surplus of Rice in Karawang District. Disertasi. IPB, Bogor.

Amaludin, Moh. 1987. Kemiskinan dan Polarisasi Sosial Studi Kasus di Desa Bulugede Kendal Jawa Tengah. U1 Press. Jakarta

Arief, Sritua dan Adi Sasono. 1984. Ketergantungan dan Keterbelakangan. Sinar Harapan. Jakarta.

Bendix, R. Dan S.M. Lipset (ed). 1963. Class, Status, and Power. A Reader in Social Stratification. Free Press of Glenco.

Colier, Wiliam L. Et.all. 1973. Recent Changes in Rice Harvesting Methods. Bulletin of Indonesian Economics Studies. Vol. IX No.2.

Colier, Wiliam L. Pendekatan Baru Dalam Pembangunan Pedesaan diJawa. Kajian Pedesaan selama 25 Tahun.

Geertz, C. 1973. Involusi Pertanian. Proses Perubahan Ekologi di Indonesia. Yayasan Obor Indonesia. Jakarta.

Nuraeni,Heny Gusti \& Muhammad Alfan. 2013. Studi Budaya Indonesia. Bandung. Pustaka Setia.

Moleong, Lexy J. 1995. Metodologi Penelitian Kualitatif. Remaja Rosdakarja. Jakarta.

Rahardjo. 2010. Pengantar Sosiologi, Pedesaan dan

Pertanian.

Yogyakarta.Gadjah Mada University Press.

Sajogyo (Penyunting). 1982. Ekologi Pedesaan: Sebuah Bunga Rampai. Yayasan Obor Indonesia. Jakarta.

Salman, Darmawan. 1995. A rah Perubahan Sosial di Pedesaan Pasca Revolusi Hijau. Analisis CSIS. Tahun XXIV. No.1.

Sarman, Mukhtar. 1994. Perubahan Status Sosial dan Moral Ekonomi Petani. Kajian Pada Komunitas Petani Plasma PIR Karet Danau Salak Kalimantan Selatan. Prisma No. 7. 
Sastra, Arif. 2002. Pengantar Sosiologi Masyarakat Pesisir. Jakarta. Pustaka Cidesndo.

Soewardi, Herman. 1976. Respon Masyarakat Desa Terhadap Modernisasi Produksi Pertanian, Terutma Padi. Gajahmada University Press. Yogyakarta.

Soyomukti, Nurani. 2010. Pengantar Sosiologi, Dasar Analisis, Teori, dan Pendekatan Menuju Analisis Masalah-Masalah Sosial, Perubahan Sosial, dan Kajian-kajian Strategis. Yogyakarta. Ar-Ruzz Madia.

Sorokin, Pitirim A. 1994. Social and Cultural Mobility. Dalam David B. Grusky (ed). Social Stratification: Class, Race, and Gender in Sosiological Perspective. Westview Press. Oxford.

Triyono, Lambang dan Nasikun. 1992. Proses Perubahan Sosial di DesaJawa. Surplus Produksi dan Pergeseran Okupasi. Rajawali Press. Jakarta.

Yong, Kenneth. 1993. Birokrat Menengah, Petani Menengah: Dimensi Ekstra Perkotaan. Dalam Richard Tanter dan Kenneth Young. Politik Kelas Menengah Indonesia. LP3ES. Jakarta. 